\title{
Császármetszést követő hüvelyi szülések vezetése a nemzetközi vélemények tükrében
}

\author{
Németh Gábor dr. - Molnár András dr. \\ Szegedi Tudományegyetem, Általános Orvostudományi Kar, Szent-Györgyi Albert Klinikai Központ, \\ Szülészeti és Nőgyógyászati Klinika, Szeged
}

\begin{abstract}
Bevezetés: A növekvő császármetszés-frekvencia világszerte egyre inkább az érdeklődés fókuszába került. A császármetszések számának csökkentésére a császármetszést követő sikeres hüvelyi szülés bizonyos esetekben kiváló módszer.

Célkitüzés: A hüvelyi szülést befolyásoló tényezők, a szülés/indukció körülményeinek, kritériumainak, rövid, illetve hosszú távú előnyöknek és következményeknek a retrospektív áttekintése.

Módszer: A császármetszést követő hüvelyi szüléssel kapcsolatos nemzetközi ajánlások és a hozzá kapcsolódó, „PubMed”, „MEDLINE”, „Cochrane” adatbázisokban 1996-2016. között megjelent közlemények feldolgozása.

Eredmények: Az ajánlások, közlemények eredményeit áttanulmányozva kijelenthetô, hogy az álláspontok bizonyos pontokban nem egységesek, viszont a császármetszést követő hüvelyi szülés egy kiváló lehetőség a szövődmények elkerülésére, a császármetszések számának csökkentésére.

Következtetések: Fontos lenne hazánkban egy egységes ajánlást megfogalmazni a császármetszést követő hüvelyi szüléssel kapcsolatosan, ami a gyakorlatban dolgozó szülész-nőgyógyász mindennapi munkáját, a legjobb döntés meghozatalát segíti.

Orv Hetil. 2017; 158(30): 1168-1174.
\end{abstract}

Kulcsszavak: császármetszés, császármetszést követő sikeres hüvelyi szülés, uterusruptura

\section{Vaginal birth after cesarean section in light of international opinions}

Introduction: The tendency of increasing cesarean section rate has drawn worldwide attention. The vaginal birth after cesarean section is a useful method to decrease cesarean section rate at defined cases.

Aim: Retrospective overview of factors resulting successful vaginal birth, labor/induction's condition, criterias, short and long term benefits and consequences.

Method: Overview recommendations of international guidelines and publications' results concerned vaginal birth after cesarean section in "PubMed", "MEDLINE", "Cochrane" databases from 1996 to 2016.

Results: Reviewing results of recommendations and publications we can declare that statements are inconsistent, however the option of vaginal birth after cesarean section is appropriate for decrease complications and trend of increasing cesarean section rate.

Conclusions: It would be important in our country to define a uniform recommendation regarding vaginal birth after cesarean section, with supporting evidence in obstetrical and gynecological practice

Keywords: cesarean section, vaginal birth after cesarean section, uterine rupture

Németh G, Molnár A. [Vaginal birth after cesarean section in light of international opinions]. Orv Hetil. 2017; 158(30): 1168-1174.

(Beérkezett: 2017. május 18.; elfogadva: 2017. június 8.)

\section{Rövidítések}

$\mathrm{BMI}=($ body mass index $)$ testtömegindex $; \mathrm{BW}=($ birth weight $)$ születési súly; CTG = (cardiotocography) kardiotokográfia; $\mathrm{EDA}=($ epidural anesthesia $)$ epiduralis anaesthesia; $\mathrm{EFW}=($ es- timated fetal weight) becsült magzati súly; ERCS = (elective repeat cesarean section) $\geq 1$ megelőző császármetszést követő tervezett császármetszés; failed TOLAC $=($ failed trial of labor after cesarean) császármetszést követől hüvelyi szülés sikertelen 
kísérlete; GDM = (gestational diabetes mellitus) terhességi cukorbetegség; NICE = (National Institute for Health and Care Excellence) Brit Nemzeti Egészségügyi és Betegellátó Intézet; $\mathrm{NIH}=$ (National Institutes of Health) Amerikai Nemzeti Egészségvédelmi Intézet; PGE-2 = prosztaglandin-E2; POP = (pelvic organ prolapse) kismedencei szervek prolapsusa; $\mathrm{RCOG}=$ (Royal College of Obstetricians and Gynecologists) Angol Királyi Szülészeti és Nőgyógyászati Társaság; SUI = (stress urinary incontinence) vizelet-stresszinkontinencia; TOLAC $=($ trial of labor after cesarean $)$ császármetszést követő hüvelyi szülés kísérlete; $\mathrm{VBAC}=$ (vaginal birth after cesarean $)$ császármetszést követő hüvelyi szülés; WHO = (World Health Organization) Egészségügyi Világszervezet

A XIX-XX. század gyakorlata az volt, hogy ha egyszer egy nó császármetszéssel szült, a következő szülés is magától értetôdően császármetszéssel kellett, hogy végződjön. Napjainkban ez a szemléletmód nagymértékben megváltozott. Az 1960-as években született tanulmányok eredményei azt mutatták, hogy nem minden esetben szükséges ismételten császármetszést végezni. 1980-ban a National Institutes of Health (NIH) -konszenzuskonferencia megkérdőjelezte a rutinmódon ismételt császármetszés elvégzésének szükségességét, és kiemelt bizonyos eseteket, amelyekben a császármetszést követő hüvelyi szülésnek (VBAC) létjogosultsága van [1]. Ennek eredményeképpen bátrabban próbáltak meg a gyakorlatban hüvelyen keresztül szülést vezetni megelőző császármetszés után, ami a VBAC emelkedését eredményezte az 1980-as évektől egészen 1996-ig. 1996-tól a VBAC száma fokozatosan csökkent, a császármetszések száma pedig növekvő tendenciát mutatott [1]. Hazánkban is ez a tendencia figyelhető meg: míg 1985-ben 10\% volt a császármetszés-frekvencia, 2000ben már 20\%-ra emelkedett, napjainkban pedig meghaladja a $38,7 \%$-ot $[2,3]$. Számos orvosi és nem orvosi tényező járult hozzá a csökkenő VBAC tendenciához. Egyértelmű orvosi indok a méh hegének szétválásától való félelem, mivel azon várandósoknál, akiknél megpróbálták a császármetszést követő hüvelyi szülést (TOLAC) és sikertelenség (failed TOLAC) miatt ismételt császármetszést kellett, hogy végezzenek, magasabb volt a komplikációk előfordulása azokhoz képest, akik az elektív ismételt császármetszést (ERCS) választották.

\section{1. táblázat | Nemzetközi vezető szervezetek}

- ACOG (American College of Obstetricians and Gynecologiests) [4]

- CNGOF (French College of Gynecologists and Obstetricians) [7]

- NICE (British National Institute for Health and Care Excellence) [18]

- NIH (American National Institutes of Health) [1]

- RCOG (Royal College of Obstetricians and Gynaecologists) [6]

- SOGC (Society of Obstetricians and Gynaecologists of Canada) [5]

- WHO (World Health Organization) [35]
A nem orvosi indikációk közül kiemelendő a VBAC-t szabályozó ajánlások, financiális megfontolások, illetve az orvosi-jogi környezet szerepe [1]. Jelen közleményünkben a nemzetközi szervezetek (1. táblázat) VBAC-vel kapcsolatos ajánlásait és az elmúlt két évtizedben született egyes cikkek eredményeit foglaljuk össze, elősegítve a gyakorlatban dolgozó szülész-nőgyógyászok döntéshozatalát VBAC kapcsán.

\section{Módszer}

Módszerünk a császármetszést követő hüvelyi szüléssel kapcsolatos nemzetközi ajánlások (1. táblázat) és a hozzá kapcsolódó, „PubMed”, „MEDLINE”, „Cochrane” adatbázisokban 1996. január és 2016. december között megjelent közlemények szisztémás retrospektív áttekintése volt. A megjelent közleményeket a következő kulcsszavak megadása alapján választottuk ki: "cesarean section", "vaginal birth after cesarean section", "uterine rupture", "maternal and perinatal outcomes", "labor induction". A kulcsszavaknak megfelelő publikációkat, ajánlásokat kronológiai sorrendben dolgoztuk fel és a témán belüli alfejezetekre vonatkozó megállapításokat, konzekvenciákat összegeztük.

\section{Eredmények}

\section{A VBAC sikerességét befolyásoló tényezők}

A VBAC sikerességi rátája $60-85 \%$ közöttire tehető [4-6]. Érdekesség, hogy a VBAC sikeressége ikerterhességek esetén a szinguláris terhességekkel azonos (69-84\%) [5-7]. A VBAC sikerességét számos tényező befolyásolja: 1. a megelőző császármetszés indikációja, 2. szülészeti és demográfiai tényezők, 3. megelőző hüvelyi szülés(ek) száma; 4. jelen terhességet jellemző tényezők (2. táblázat). A VBAC szempontjából kedvező, ha a megelőző császármetszés indikációja például medencevégú hosszfekvés volt [8], ami 82\%-os VBAC-sikerességi rátát eredményez [9], szemben például a téraránytalansággal, ami szignifikánsan csökkenti a sikerességet. A VBAC sikerességét befolyásolja az anyai életkor, faji/ etnikai hovatartozás; egyedülálló anya, alacsonyabb iskolázottság, magán vagy közintézményben való szülés ténye, anyai testmagasság, testtömegindex (BMI). Az anyai életkor tekintetében nincs egyértelmú korhatár, ami felett alacsonyabb lenne a VBAC előfordulása, habár megfigyelték, hogy a 35 évnél idősebb nők kisebb arányban vállalják a hüvelyi szülést, mint a fiatalabb korosztály $[10,11]$. A 12 évnél alacsonyabb iskolai végzettség az afroamerikaiaknál és hispániaiaknál alacsonyabb, mint a nem hispániai fehéreknél, $B M I>30 \mathrm{~kg} / \mathrm{m}^{2}$, anya krónikus betegsége (hypertonia, asthma bronchiale, cukorbetegség, szívbetegség) csökkenti a sikerességet [1]. Általánosságban elmondható, hogy a pregesztációs diabetes mellitus csökkenti a VBAC sikerességét, de gesztációs diabetes mellitus (GDM) esetén hiányzó macrosomia nem befo- 
2. táblázat $\mid$ A VBAC sikerességét támogató és csökkentő tényezők

\begin{tabular}{|c|c|}
\hline $\begin{array}{l}\text { VBAC sikerességét támogató } \\
\text { tényezők }\end{array}$ & $\begin{array}{l}\text { Megelőző császármetszés } \\
\text { indikációja magzati okból, } \\
\text { például medencevégü } \\
\text { hosszfekvés. } \\
\text { Anyai testmagasság, } \\
\text { BMI<30 kg/m². } \\
\text { Pvn császármetszés előtti vagy } \\
\text { utáni (császármetszés előtt } \\
1 \text { pvn: } 83 \% \text {; császármetszés utáni } \\
1 \text { pvn: } 94 \% \text { VBAC). } \\
\text { BW<4000 g. } \\
\text { Méhszájstátusz felvételkor/ } \\
\text { burokrepedés/burokrepesztéskor } \\
\text { (Bishop-score } \geq 6 \text { ). }\end{array}$ \\
\hline $\begin{array}{l}\text { VBAC sikerességét csökkentő } \\
\text { tényezők }\end{array}$ & $\begin{array}{l}\text { Megelőző császármetszés } \\
\text { indikációja anyai okból, például } \\
\text { téraránytalanság, cervixdystocia. } \\
\text { Magasabb anyai életkor, } \\
\text { egyedülálló anya, } 12 \text { évnél } \\
\text { alacsonyabb iskolázottság. } \\
\text { Anyai betegség (például } \\
\text { hypertonia, diabetes mellitus, } \\
\text { asthma bronchiale, vesebetegség, } \\
\text { pajzsmirigybetegség, } \\
\text { szívbetegség). } \\
\text { 40. terhességi hét utáni szülés, } \\
\text { szülésindukció, fájáserósítés. }\end{array}$ \\
\hline
\end{tabular}

BMI = testtömegindex $\left(\mathrm{kg} / \mathrm{m}^{2}\right) ; \mathrm{BW}=$ születési súly $(\mathrm{g}) ; \mathrm{pvn}=$ hüvelyi szülés; VBAC $=$ császármetszést követô hüvelyi szülés

lyásolja, tehát bármely fajta macrosomia nélküli cukorbetegség esetén a VBAC megkísérelhető $[4,7]$. A 4000 g feletti magzati születési súly (BW) megduplázza az uterusruptura előfordulását $[2,5]$, tehát csökkenti a sikerességi rátát. $4500 \mathrm{~g}$ feletti becsült magzati súly (EFW) esetén ERCS a választandó [7]. Az anamnézisben szereplő multiparitás és hüvelyi szülés kedvezően befolyásolja a VBAC-t. Egy tanulmány kimutatta, hogy a VBAC előfordulása olyan nőknél, akiknél nem szerepelt az anamnézisben hüvelyi szülés, $63 \%$, akiknél a császármetszés előtt volt pvn, 83\%, akiknél egy megelőző VBAC, azoknál 94\%-nak bizonyult. Kiemelendő a császármetszés és az azt követő hüvelyi szülés között eltelt időintervallum fontossága. Az uterusruptura előfordulása 2,65\%-os 24 hónapnál kevesebb eltelt idő esetén [12], habár kedvező szülészeti tényezők meglétekor hat hónapos intervallum után engedélyezett a VBAC [7]. A betöltött 40. terhességi hét utáni kor, kedvezőtlen méhszájstátusz (Bishopscore $<6)$, szülésindukció és fájáserősítés csökkenti a VBAC sikerességét, mivel emelkedik a méhtestrepedés előfordulása. Nem létezik klinikailag megalapozott scoringrendszer, ami előre jelezné a VBAC százalékos sikerességét, azonban a Maternal-Fetal Medicine Units Network honlapon egy kalkulátor segítségével a hüvelyi szülés sikerességi rátája kiszámolható [13].

\section{Tájékoztatás, sziülés időpontjának idözitése}

Az orvosi tájékoztatásnak alapvető szerepe van abban, hogy a várandós hozzájáruljon az orvosi döntéshez [14, 15]. Ennek alapján kiemelkedően fontos a részletes felvilágosítás a szülési módok előnyeinak és hátrányainak ismertetése, az adott terhességben lévő rizikótényezők figyelembevételével és a szülés időzítéséről való tájékoztatás. Lehetőleg kerülni kell az „egyszer császármetszés, mindig császármetszés” kifejezést. Több közlemény kihangsúlyozza, hogy a végső döntést gyakorlott szülésznőgyógyász szakorvosnak kell meghozni a várandós nő bevonásával [1]. Vannak adatok, amelyek szerint a terhesgondozás során a könnyebb döntés meghozatalát célzó teljes körű tájékoztatás a VBAC előfordulását nem csökkentik, de növelik a várandósok szülési módokról való ismeretét, illetve csökkentik a szülés körüli döntési bizonytalanságot [16]. Mivel a császármetszést követő szülési módok fokozott rizikót jelentenek mind az anyára, mind a magzatra, kiemelkedő fontosságú a dokumentáció. Ismertetni kell a szülési módokkal kapcsolatosan mind a magzat, mind az anya rövid, illetve hosszú távú rizikóit, következményeit, kiemelve az uterusrupturát, ami a szülés módjának megválasztásában döntő tényező. Mivel a VBAC potenciális rizikótényezői már a kora terhességben ismertek, a szülés módját már a kora terhességi tanácsadáson meg tudjuk jósolni, előre tudjuk vetíteni [4], de a végső döntésről a szülés körüli periódusban kell nyilatkozni, elég időt hagyva a gondolkozásra [17]. Az ERCS-t a betöltött 39. terhességi hét után ajánlatos elvégezni [6]. Nemzetközi ajánlások a meg nem indult szülés esetén alkalmazott szülésindukció elvégzését a betöltött $41+0$ terhességi hétig engedélyezik $[6,18]$.

\section{Tárgyi, személyi feltételek, a szülésvezetés kritériumai}

A VBAC fekvőbeteg-intézményben kell hogy történjen [5]. Az egészségügyi ellátószemélyzetnek a nap 24 órájában készen kell állnia a sürgős császármetszés elvégzésére, esetleges komplikációk szakszerü ellátására $[5,7]$. A mütét elvégzéséhez szükséges a megfelelő képzettség, gyakorlat; a sürgősségi esetek (például transzfúzió) azonnali ellátásának biztosítása, abban való jártasság. A nemzetközi ajánlások a döntéshozatal és a császármetszés elvégzése között eltelt idő meghatározásában nem egységesek: például Németországban 20 perc, Kanadában 30 perc. Rendszeres fájásoktól kiemelendő a folyamatos monitorizálás (CTG) $[4,5,7]$, mivel az esetleges uterusrupturára leghamarabb a magzati szívfrekvencia-változásból tudunk következtetni a vajúdó egyre romló általános állapota mellett $[4,5,7]$. A szülés progressziójának nyomon követése fontos, mivel a nem megfelelő fájások következtében a szülés elhúzódhat, ami uterusrupturát eredményezhet, csökkentve a VBAC sikerességét [5, 7]. A rendelkezésünkre álló adatok alapján az epiduralis érzéstelenítésnek (EDA) nincs negatív hatása a VBAC-re 
[4]. A szülés előtti hegvonalvastagság meghatározása céljából elvégzett ultrahangvizsgálatnak döntő szerepe lehet az uterusruptura előrejelzésében. Metaanalízisek ellenére sajnos egyértelmű „cut-off” érték nem áll rendelkezésünkre [19-21], illetve a gyakorlatban tapasztalt megmért hegvonalvastagság nem mindig korrelál a szülés lezajlásának módjával, például egy egészen vékonynak mért hegvonal mellett is sikeresen, komplikációmentesen szülnek hüvelyen keresztül. A sikeresen lezajlott VBAC után a hegvonal épségének megítélése céljából elvégzett manuális méhưri betapintás nem szükséges, sőt esetenként kóros is lehet $[4,5,7]$.

\section{Előnyök és hátrányok az anya, illetve a magzat szempontjából VBAC esetén}

\section{Rövid távú elönyök és hátrányok az anya szempontjából (VBAC vs. ERCS)}

Az ajánlások egyértelmúen alátámasztják, hogy az anyai mortalitás legalacsonyabb VBAC esetén, míg legmagasabb sikertelen TOLAC-ot követő császármetszés alkalmával. Az adatok nem egységesek az anyai mortalitás tekintetében. A kanadai ajánlás szerint VBAC esetén emelkedettebb [22], míg a NIH-ajánlás szerint az anyai mortalitás alacsonyabb ERCS-vel összehasonlítva (VBAC vs. ERCS: 1,9/100 000 vs. 9,6/100 000) [1]. Az elvégzett hysterectomia tekintetében az adatok szintén eltérőek. Egyes ajánlások szerint nincs különbség [1] annak ellenére, hogy a súlyos szövődmények előfordulása VBAC tekintetében megduplázódik, míg egyes közlemények azt állítják, hogy VBAC esetén alacsonyabb a hysterectomia előfordulása [23]. Sebészeti sérülések és az infekció kialakulásának gyakorisága magasabb sikertelen TOLAC esetén ERCS-vel összehasonlítva. Uterusruptura esetén 14-33\%-ban kényszerülünk hysterectomia elvégzésére. Egyértelmúen kijelenthető, hogy a VBAC esetén ritkábban jelentkezik láz, kevesebb a thromboembolia előfordulása, rövidebb a kórházi ápolási napok száma és gyorsabb a felépülés $[1,5,7]$. Az uterusruptura előfordulási gyakorisága VBAC esetén emelkedettebb $(0,1-1,6 \%) \quad[1,4,5,7]$, ERCS esetén $0,03-0,19 \%[1,5]$. A korábbi császármetszés előtti vagy utáni hüvelyi szülés protektív hatással van az uterusruptura kialakulására. Az első VBAC esetén 1,6\%, míg a második alkalmával 0,2\%-ra csökken az előfordulása [5, 24]. Nincs egyértelmú összefüggés a varrási technika (tovafutó/csomós) és az uterusruptura kialakulása között [5, 7]. Előfordulását befolyásoló tényezők: metszés típusa (longitudinális után gyakoribb, mint transzverzális után); szülésindukció; 40. hét utáni terhességi kor vs. 37-40. hét között; korábbi császármetszés(ek) száma, méhszájstátusz (Bishop-score $\geq 6$ ); obesitas $\left(\mathrm{BMI}>30 \mathrm{~kg} / \mathrm{m}^{2}\right)$; $4000 \mathrm{~g}$ feletti BW; 24 hónapnál kevesebb eltelt időintervallum a császármetszés és TOLAC között [1].

\section{Hosszú távú elönyök \\ és hátrányok az anya szempontjából \\ (VBAC vs. ERCS)}

Hosszú távú előnyként kiemelendő, hogy VBAC után kisebb az esély a lepény tapadási (placenta praevia), beágyazódási rendellenességek (placenta accreta, increta, percreta) és lepényleválás kialakulására $[5,25]$. Alacsonyabb a méhen kívüli terhesség, a krónikus kismedencei fájdalom, infertilitás, vetélés, összenövések, transzfúzió adása és bél- illetve hólyagsérülés előfordulása is VBAC után ERCS-vel összehasonlítva. Hosszú távú hátrányként a női kismedence funkcióromlása említendő meg (például kismedencei szervek prolapsusa [POP], stresszinkontinencia [SUI]).

\section{Rövid és hosszú távú elönyök illetve hátrányok a magzat szempontjából (VBAC vs. ERCS)}

Mind a perinatalis $(0,13$ vs. $0,05 \%)$, mind a neonatalis $(1,11$ vs. $0,05 \%)$ mortalitás alacsony VBAC esetén, de magasabb ERCS-vel összehasonlítva $[1,5]$, aminek magyarázata a VBAC esetén a magasabb uterusruptura előfordulása [5]. VBAC esetén a hypoxiás, ischaemiás encephalopathia incidenciája magasabb (prevalencia VBAC vs. ERCS: $0,5-2,3 / 1000$ vs. 0-1,1/1000) [7]. Gyakrabban fordul elő szülés alatti magzati sérülés, például plexus brachialis sérülés (VBAC vs. ERCS: 180 vs. $30 / 100000)$. A francia ajánlás szerint a szepszis előfordulása emelkedett VBAC esetén (VBAC vs. ERCS 2 vs. 0\% [7]), míg a NIH [1] szerint nincs különbség. Az újszülöttkori hyperbilirubinaemia (VBAC vs. ERCS: 2,2\% vs. 5,8\%) [4] és a neonatalis respirációs problémák (tachypnoe) előfordulása alacsonyabb VBAC esetén (ERCS vs. VBAC: $6 \%$ vs. $3 \%)[4,5]$.

\section{A VBAC kontraindikációi}

VBAC ellenjavallt, ha korábban a méhen ejtett metszés longitudinális irányú vagy $\mathrm{T}$ metszés volt $[4,5,7]$. Az amerikai ajánlás a korábban az uterus alsó szegmentumán ejtett vertikális metszés után is engedélyezi a hüvelyi szülést. Nem engedélyezett a VBAC, ha a várandós nem egyezik bele a hüvelyi szülésbe [5]; placenta praevia, fekvési rendellenességek esetén $[4,5]$, ha az anamnézisben uterusruptura szerepel $[4,5,7]$, mivel az ismételt méhrepedés előfordulása 6-32\%. Általánosságban elfogadott az a tény, hogy három vagy annál több megelőző császármetszés esetén nem engedélyezett a hüvelyi szülés, habár két megelőző császármetszés után az uterusruptura esélye megnő $[7,26]$, de vannak adatok, amik azt bizonyítják, hogy a rizikó előfordulása szignifikánsan nem magasabb [27]. 


\section{A szülésindukció idözitése és módszerei császármetszést követö büvelyi szülés esetén}

Szülésindukció időpontja tekintetében szintén nem egységesek az álláspontok. A NICE [18] ajánlásában említést tesz, hogy egészen a betöltött $41+0$. hétig engedélyezi a várakozást a szülésindukcióval, habár nem egyértelmű, hogy ez a megelőző császármetszés esetén is egyszerúen alkalmazható, mivel császármetszés után a méhen belüli magzati veszteség a 39. hét után másfélkétszeresére nő [28]. A szülésindukció maga a sürgősségi császármetszést másfélszeresére és a méhtestrepedést két-háromszorosára emeli. Mindezeket figyelembe véve az RCOG [6] úgy határozott, hogy ha megelőző császármetszés utáni várandósoknál terminusközelben nincs jele a spontán hüvelyi szülés megindulásának, akkor a $41+0$. héten tapasztalt szülész-nőgyógyász szakorvosnak hüvelyi vizsgálatot kell végeznie. A VBAC sikerességét támogató tényezők figyelembevételével kell megbeszélni a várandóssal a szülés módját (VBAC vagy ERCS) és TOLAC esetén a szülésindukció lehetséges módszereit (mechanikai vagy gyógyszeres). ERCS a $41+3$. terhességi héten végzendő, alkalmas esetben TOLAC a választandó.

Szülésindukcióként, illetve fájáserősítésként alkalmazott oxitocint illetően eltérő a gyakorlat Magyarországon TOLAC esetén. Vannak intézmények, ahol engedélyezett, vannak, ahol tiltott az oxitocin bármiféle használata megelőző császármetszés után az esetleges hegszétválástól való félelem miatt [29]. Nemzetközi ajánlások szülésindukció alkalmával használt oxitocin adását érett méhszáj esetén engedélyezik $[5,7]$. Éretlen méhszáj (Bishop-score<6) esetén jelentősen emelkedik az uterusruptura előfordulása. Született egy tanulmány, ahol 142075 VBAC 43\%-ában használtak oxitocint, és az uterusruptura 0,62\%-ban fordult elő [30]. Összehasonlították az uterusruptura százalékos előfordulását akkor, ha az oxitocint szülésindukcióként vagy csak fájáserősítőként alkalmazták. Azt tapasztalták, hogy szülésindukcióban adott oxitocin esetén emelkedettebb az uterusruptura előfordulása, mint amikor csak fájáserôsítőként alkalmazták $(1,1$ vs. $0,8 \%)[4,31]$. A kialakulás dózisfüggő, a pontos mennyiség nem definiált. Az oxitocin adása előtt alkalmazott prosztaglandin tovább emeli a ruptura esélyét az oxitocin önmagában történő használatához képest $(1,4-2,24 \%)[4,32,33]$.

A prosztaglandin-E2 (PGE-2) adásával kapcsolatosan sincs egységes nemzetközi ajánlás. Amerikában [4] csak VBAC tekintetében kedvező eséllyel rendelkezőknél engedélyezte a gyógyszer használatát, Kanadában kontraindikált [3], kivéve bizonyos, egyedi eseteket, míg Franciaországban [7] csak nagy körültekintéssel használható. Magasabb az uterusruptura előfordulása amniotomia, oxitocin vagy Foley-katéter-használattal összehasonlítva. Angliában a 2008-as NICE-ajánlás [18] engedélyezte, míg az RCOG javaslata nagy óvatossággal való használatra int [6]. A Cochrane adatbázis elégtelen bizonyíté- kok birtokában kijelenti, hogy a PGE-2 használata „offlabel”-nek minősül [33]. A misoprostol megelőző császármetszés utáni használata nem ajánlott a magas uterusruptura-kialakulás miatt $(18,8 \%)$ [34].

A WHO [35], a kanadai és amerikai ajánlások [4, 5] a transcervicalis ballonkatéter használatát javasolják szülésindukció lehetséges módszereként, mivel állításuk szerint az uterus-hiperstimuláció és az uterusruptura kialakulása nem nő. Mélyen, illetve elöl fekvő lepény esetén a használata kontraindikált.

Az eredményeket röviden összefoglalva elmondható, hogy a VBAC sikerességi rátája 60-85\% [4-6]. Alacsony a szövődmények előfordulása, viszont sikertelen TOLAC esetén elvégzett császármetszés alkalmával növekszik. Az uterusruptura VBAC esetén $0,5 \%$. A perinatalis és neonatalis mortalitás, morbiditás extrém alacsony, viszont valamivel magasabbak az ERCS-ben tapasztaltakhoz képest, kivéve a neonatalis respirációs morbiditást (tachypnoe). A császármetszések növekedésével számolnunk kell az egyre gyakrabban előforduló lepénytapadási és beágyazódási rendellenességek, méhen kívüli terhességek, krónikus kismedencei fájdalom, infertilitás, vetélés, összenövések, bél- és hólyagsérülés kialakulásával. ERCS ideális időzítése a betöltött 39. hét után javasolt. A szülés mindenképpen olyan egészségügyi intézményben kell, hogy történjen, ahol jól képzett személyzet az azonnali császármetszést el tudja végezni. Szülésindukcióként alkalmazott burokrepesztés és oxitocin kedvező méhszájstátusz esetén engedélyezett (Bishop-score $\geq 6$ ), habár a szülésindukcióban használt mechanikai módszerek (ballonkatéter, burokrepesztés) alacsonyabb rizikóval bírnak a gyógyszeressel szemben (prosztaglandin, oxitocin). Szülésindukció alkalmával mindig tájékoztatni kell a várandóst arról, hogy az uterusruptura két-háromszorosára, az ismételt császármetszés esélye másfélszeresére emelkedik. Fájáserősítésként oxitocin használható, de csak tapasztalt szülész-nőgyógyász szakorvos rendelheti el. Fájdalomcsillapításként használt EDA engedélyezett folyamatos CTG-monitorizálás mellett, mivel az esetleges uterusruptura jelei a regisztrátumon jelentkeznek leghamarabb. VBAC után a hegvonal ellenőrzése céljából végzett manuális méhứri ellenőrzés nem előnyös.

\section{Megbeszélés}

A XX. században elfogadott kijelentés, miszerint az „egyszer császármetszés, mindig császármetszés” („once a cesarean, always a cesarean”) a XXI. századra érvényét vesztette. Az orvos egyre több olyan, korábban császármetszéssel szült várandóssal találkozott, ahol felmerült az anyai és magzati rizikó mérlegelésével a kedvezőbb hüvelyi szülés lehetősége az ERCS-vel szemben. Az anyai, illetve magzati rizikót figyelembe véve paradigmaváltás indult a vezető nemzetközi szervezetek részéről a császármetszést követő szülés módját illetően. A nemzetközileg elismert társaságok ajánlásait áttanulmányozva kijelenthető, hogy a VBAC-vel kapcsolatos álláspon- 
tok nem egységesek (például szülésindukció időpontja, módszerek stb.), viszont a VBAC egy kiváló lehetőség a szövődmények elkerülésére, a császármetszések számának csökkentésére. Bármelyik szülési mód mellett is döntünk (VBAC/ERCS), a döntéshozatal nem egyszerú, mivel figyelembe kell vennünk a rövid, illetve hosszú távú előnyöket és hátrányokat nemcsak az anya, hanem a magzat szemszögéből is, amelyek néha egymástól különböznek. Nemcsak az anyának, hanem a döntést meghozó, szülésért felelős orvosnak is nagy dilemma, mivel a választott szülésmód az anyának lehet, hogy alacsonyabb rizikót jelent, ugyanakkor ez a magzat szempontjából épp az esetleges szövődmények kialakulását okozhatja. A gyakorló orvosnak alapvető befolyása van a várandós nő döntéshozatalára akár a VBAC-t, akár az ERCS-t választja $[14,15]$. Ennek alapján kiemelkedően fontos a részletes felvilágosítás az orvos részéról, a szülésmódok mellett és ellene kialakított érveinek ismertetése, időzítése, rizikókról való tájékoztatás és a várandós végső döntésbe való bevonása.

A VBAC sikeressége szempontjából kiemelendő a hazánkban is nagy egészségügyi problémát jelentő anyai elhízás csökkentése, mivel a kóros BMI csökkenti a császármetszés utáni hüvelyi szülés esélyét [1]. GDM esetén fontos a szoros cukorháztartás-kontroll, mert kimutatott, hogy a macrosomia hiánya hozzájárul a VBAC sikerességéhez $[5,7]$.

\section{Következtetés}

A mindennapi gyakorlatban dolgozó szülész-nőgyógyásznak óriási segítség egy olyan ajánlás megléte, amire az adott helyzetben szükséges döntés meghozatalakor támaszkodhat. Fontos lenne Magyarországon egy egységes szakmai álláspontot megfogalmazni a VBAC-vel kapcsolatosan, ami a meglévő tényezőket/faktorokat figyelembe véve segítené az orvosok mindennapi munkáját, a legjobb döntés meghozatalát. Jogi szempontból is kiemelkedő fontosságú lenne, mivel az esetleges szövődmények kialakulása következtében indított kártérítési perektől való félelem nagyban befolyásolja döntésünket.

Véleményünk szerint a gyakorlatban a VBAC szempontjából ideális tényezők esetén a szülőnő teljes körú felvilágosítása, beleegyező nyilatkozat aláíratása után az oxitocin használata megengedhető folyamatos CTGmonitorizálás mellett. Méhszájérlelés céljából prosztaglandin készítmény használatát nem javasoljuk. Támogatandó a szülési fájdalomcsillapításként alkalmazott epiduralis érzéstelenítés. Egyrétegben való varrási technikát alkalmazunk a méhen ejtett sebzés zárására, ügyelve az endometriumszélek gondos egyesítésére a későbbiekben kialakuló „niche” elkerülése céljából. Hüvelyi szülést követően a hegvonal ellenőrzése céljából elvégzett manuális méhúri revíziót nem javasoljuk a hegvonal iatrogén sérülésének elkerülésére, kivéve megindult bő méhüri vérzés esetén.
Anyagi támogatás: A közlemény megírása anyagi támogatásban nem részesült.

Szerzői munkamegosztás: N. G., M. A.: A kézirat kidolgozása és szövegezése. A cikk végleges változatát mindkét szerző elolvasta és jóváhagyta.

Érdekeltségek: A szerzőknek nincsenek érdekeltségeik.

\section{Irodalom}

[1] National Institutes of Health Consensus Development Conference Panel. National Institutes of Health Consensus Development Conference Statement: Vaginal birth after caesarean: new insights March 8-10, 2010. Obstet Gynecol. 2010; 115: 12791295 .

[2] Central Statistical Office. [Központi Statisztikai Hivatal]. Avaliable from: https://www.ksh.hu. [Hungarian]

[3] Nagy S. Changing trends and indications for cesarean section in the last few decades. [A császármetszés javallatainak változása az elmúlt évtizedekben]. Orv Hetil. 2014; 155: 1140-1146. [Hungarian]

[4] American College of Obstetricians and Gynecologists. ACOG Practice bulletin no. 115: Vaginal birth after previous caesarean delivery. Obstet Gynecol. 2010; 116: 450-463.

[5] Society of Obstetricians and Gynaecologists of Canada. SOGC clinical practice guidelines. Guidelines for vaginal birth after previous caesarean birth. Number 155 (Replaces guideline Number 147), February 2005. Int J Gynaecol Obstet. 2005; 89: 319331.

[6] Royal College of Obstetricians and Gynaecologists. RCOG Green-top Guideline No. 45: Birth after previous caesarean birth. October 2015. [accessed: 07.01.2016].

[7] Sentilhes L, Vayssière C, Beucher G, et al. Delivery for women with a previous caesarean: guidelines for clinical practice from the French College of Gynecologists and Obstetricians (CNGOF) Eur J Obstet Gynecol Reprod Biol. 2013; 170: 25-32.

[8] Weinstein D, Benshushan A, Tanos V, et al. Predictive score for vaginal birth after caesarean section. Am J Obstet Gynecol. 1996; 174: 192-198.

[9] McMahon MJ, Luther ER, Bowes WA, et al. Comparison of a trial of labor with an elective second caesarean section. N Engl J Med. 1996; 335: 689-695.

[10] Wells EC, Cunningham GF. Choosing the route of delivery after cesarean birth. Wolters Kluver Health, UpToDate. 2013.www. uptodate.com

[11] Gyarmati, B. Medical and sociological factors contributing to increasing rates of Cesarean sections. [A császármetszés növekvő arányának orvosi és társadalmi okai.] PhD dissertation. Doctoral School, University of Pécs, Pécs, 2010. [Hungarian]

[12] Bujold E, Mehta $\mathrm{SH}$, Bujold $\mathrm{C}$, et al. Interdelivery interval and uterine rupture. Am J Obstet Gynecol. 2002; 187: 1199-1202.

[13] Eunice Kennedy Shriver National Institute of Child Health and Human Development. Maternal-Fetal Medicine Units Network. Available from: https://mfmunetwork.bsc.gwu.edu/PublicBSC/MFMU/VGBirthCalc/vagbirth.html [accessed: May 22, 2014].

[14] Kline J, Arias F. Analysis of factors determining the selection of repeated caesarean section or trial of labor in patients with histories of prior caesarean delivery. J Reprod Med. 1993; 38: 289292.

[15] McMahon MJ. Vaginal birth after caesarean. Clin Obstet Gynecol. 1998; 41: 369-381.

[16] Nilsson C, Lundgren I, Smith V, et al. Women-centred interventions to increase vaginal birth after caesarean section (VBAC): A systematic review. Midwifery 2015; 31: 657-663. 
[17] Reif P, Brezinka C, Fischer T, et al. Labour and childbirth after previous caesarean section: Recommendations of the Austrian Society of Obstetrics and Gynaecology (OEGGG). Geburtshilfe Frauenheilkd. 2016; 76: 1279-1286.

[18] National Institute for Health and Care Excellence. NICE Guidance and guidelines. Induction of labour 2008. Available from: https://www.nice.org.uk/guidance/qs60 [accessed: July 1, 2016].

[19] Rozenberg P, Goffinet F, Phillippe HJ, et al. Ultrasonographic measurement of lower uterine segment to assess risk of defects of scarred uterus. Lancet 1996; 347: 281-284.

[20] Rozenberg P, Goffinet F, Philippe HJ, et al. Thickness of the lower uterine segment: its influence in the management of patients with previous caesarean sections. Eur J Obstet Gynecol Reprod Biol. 1999; 87: 39-45.

[21] Kok N, Wiersma IC, Opmeer BC, et al. Sonographic measurement of lower uterine segment thickness to predict uterine rupture during a trial of labor in women with previous Cesarean section: a meta-analysis. Ultrasound Obstet Gynecol. 2013; 42: 132-139.

[22] Mozurkewich EL, Hutton EK. Elective repeat caesarean delivery versus trial of labor: a meta-analysis of the literature from 1989 to 1999. Am J Obstet Gynecol. 2000; 183: 1187-1197.

[23] Rageth JC, Juzi C, Grossenbacher H. Delivery after previous caesarean: a risk evaluation. Swiss Working Group of Obstetric and Gynecologic Institutions. Obstet Gynecol. 1999; 93: 332337.

[24] Shimonovitz S, Botosneano A, Hochner-Celnikier D. Successful first vaginal birth after caesarean section: a predictor of reduced risk for uterine rupture in subsequent deliveries. Isr Med Assoc J. 2000; 2: 526-528.

[25] Sholapurkar SL. Long-term complications of caesarean section an inevitable consequence? BJOG 2014; 121: 1445-1446.

[26] Tahseen S, Griffiths M. Vaginal birth after two caesarean sections (VBAC-2)-a systematic review with meta-analysis of success rate and adverse outcomes of VBAC-2 versus VBAC-1 and repeat (third) caesarean sections. BJOG 2010; 117: 5-19.
[27] Asakura H, Myers SA. More than one previous caesarean delivery: a 5-year experience with 435 patients. Obstet Gynecol. 1995; 85: 924-929.

[28] Smith GCS, Pell JP, Dobbie R. Caesarean section and risk of unexplained stillbirth in subsequent pregnancy. Lancet 2003; 362: 1779-1784.

[29] Adam Zs. Vaginal birth after cesarean delivery. [Hüvelyi szülés megelőző császármetszés után]. Presentation. 63. Consilium

[30] Chauhan SP, Martin JN, Henrichs CE, et al. Maternal and perinatal complications with uterine rupture in 142,075 patients who attempted vaginal birth after caesarean delivery: a review of the literature. Am J Obstet Gynecol. 2003; 189: 408-417.

[31] Landon MB, Hauth JC, Leveno KJ, et al. Maternal and perinatal outcomes associated with a trial of labor after prior caesarean delivery. N Engl J Med. 2004; 351: 2581-2589.

[32] Lydon-Rochelle M, Holt VL, Easterling TR, et al. Risk of uterine rupture during labor among women with a prior caesarean delivery. N Engl J Med. 2001; 345: 3-8.

[33] Jozwiak M, Dodd JM. Methods of term labour induction for women with a previous caesarean section. Cochrane Database Syst Rev. 2013; CD009792.

[34] Blanchette HA, Nayak S, Erasmus S. Comparison of the safety and efficacy of intravaginal misoprostol (prostaglandin El) with those of dinoprostone (prostaglandin E2) for cervical ripening and induction of labor in a community hospital. Am J Obstet Gynecol. 1999; 180: 1551-1559.

[35] World Health Organization. WHO recommendations for induction of labour. WHO, 2011. Available from: http://www.who. int/reproductivehealth/publications/maternal_perinatal_ health/9789241501156/en/ [accessed: January 14, 2016]

(Molnár András dr., Szeged, Semmelweis u. 1., 6725 e-mail: md.andrasmolnar@gmail.com)

\section{„Non omne, quod nitet, aurum est." (Nem mind arany, ami fénylik.)}

